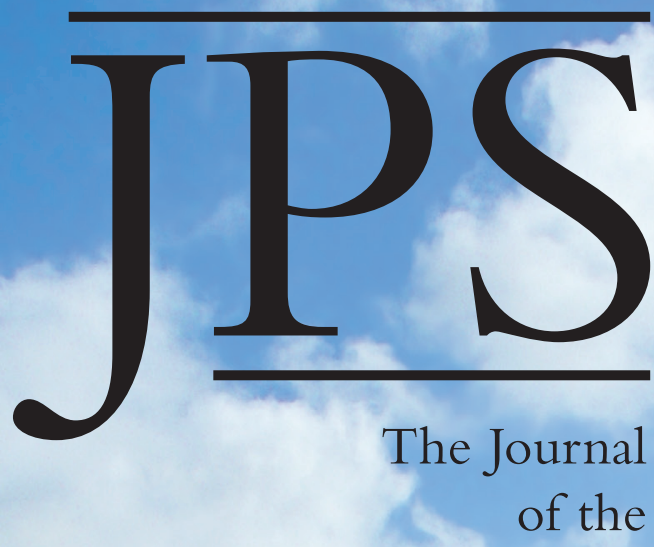

Polynesian Society

VOLUME 125 No.4 DECEMBER 2016

THE POLYNESIAN SOCIETY

1.t. THE UNIVERSITY OF AUCKLAND NEW ZEALAND

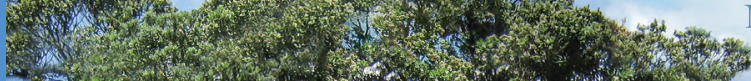

1.2.

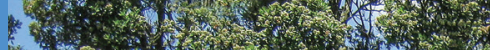

(2)

F.t.

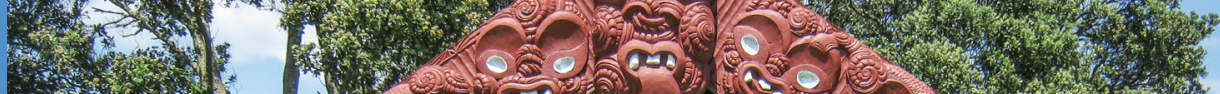

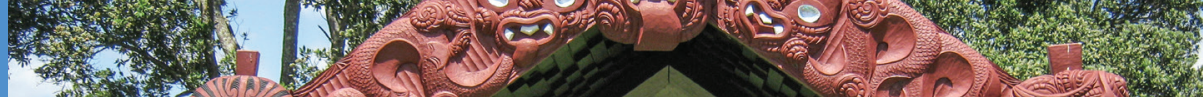

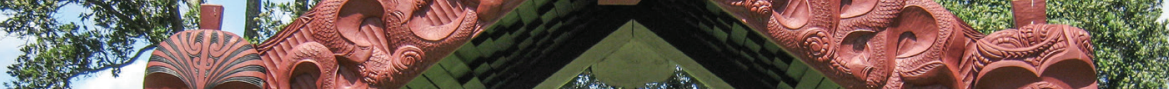

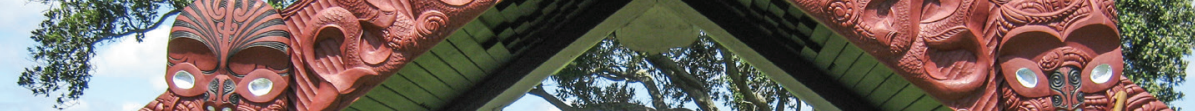

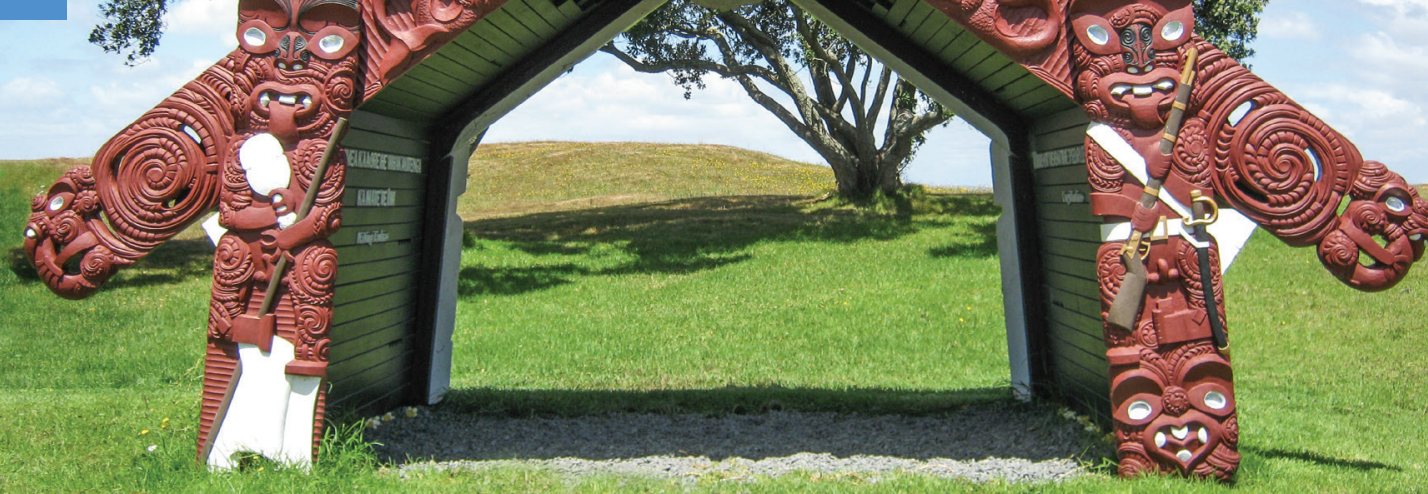




\title{
A TALE OF TWO RANGATIRA: REWI MANIAPOTO, WIREMU TAMIHANA AND THE WAIKATO WAR
}

\author{
VINCENT O’MALLEY \\ HistoryWorks
}

\begin{abstract}
This is a tale of two rangatira or 'chiefs', Wiremu Tamihana and Rewi Maniapoto, of Ngāti Hauā and Ngāti Maniapoto respectively. And if a trend that runs deep in New Zealand historiography is in any way accepted as legitimate, it is also a tale of good versus evil, moderation versus extremism, peace advocate versus warmonger. Except that it is none of these things. If we are going to conceptualise the differences between these two great rangatira in European terms, a more accurate description might be idealist and realist. Considered within the context of Māori custom, however, both men operated within the accepted limits of chiefly behaviour, which placed a premium on mana 'power, authority, prestige' and actions and virtues that were seen as befitting rangatira of great standing. Rangatira "demonstrated or enhanced their mana through qualities such as bravery, boldness, hospitality, eloquence, integrity, and honourableness" (Ward 1997 [II]: 9). These were all qualities that both men possessed in abundance. But rangatira could and did perform different functions within their communities and that is also apparent in the life stories of these two men (Ballara 1991: 292).
\end{abstract}

\section{RANGATIRA IN MĀORI SOCIETY}

Rangatira status was mainly determined by genealogical status and gender, with the first-born son of the incumbent senior chief often identified as the likely successor (Winiata 1967: 28). Mana was a key driver in Māori society and was not fixed but could wax and wane with the fortunes of the rangatira, deriving from both ascription and achievement (Durie 1994: 36-37). Since the chief's mana was the embodiment of the mana of the hapi ' 'genealogical descent group' both parties had a vested interest in protecting and enhancing the rangatira's standing (Durie 1994: 39). First-born sons might be set aside in the event that others showed greater aptitude. All free-born members of the community held mana, although their authority and status differed greatly. Those who demonstrated acknowledged skills in particular endeavours, such as leading their hapu in fighting, might be acknowledged as the leader for these purposes alone, although the authority of rangatira was never absolute and decision-making was "a matter of discussion, compromise and consensus" that relied upon the voluntary consent of the community (Ballara 1998: 145). Persons with known abilities in oratory or diplomacy might be 
designated to lead peace-making parties. Women were also called upon to perform this role (Ballara 2003: 158-60). Although most rangatira were men, at times women might also exercise leadership within their communities, and the tribal assemblies at which many decisions were made were often attended by both sexes (O'Malley 2012: 209). In the post-contact era, mana might be demonstrated in a variety of new ways: through association with the missionaries, for example, successful trading endeavours or as a result of government recognition (Durie 1994: 40). The "pursuit of mana" in these ways continued in a vastly different environment and context (Parsonson 1981: 142).

\section{REWI MANIAPOTO AND WIREMU TAMIHANA}

Rewi Maniapoto and Wiremu Tamihana were both leading rangatira within the Waikato-Maniapoto confederation of tribes that included Ngāti Maniapoto, Ngāti Hauā and other Waikato groups which came to take a leading role in the establishment of the Kinngitanga (the Māori King Movement). Tarapipipi Te Waharoa was born at Tamahere in the central Waikato in the early 19th century. The son of senior Ngāti Hauā rangatira (and famed military leader) Te Waharoa, as a young man Tarapipipi accompanied his father on a number of fights against other tribes during the height of the "musket wars" (Stokes 2002: 23). In 1835 a Church Missionary Society station was established close to Te Waharoa's own Matamata $p \bar{a}$ 'fortified village', near the presentday settlement of Waharoa. Although the mission station was subsequently abandoned, Tarapipipi forged a close personal relationship with the missionary Alfred Nesbit Brown and quickly learned to read and write (Stokes 2002: 28). Despite being the second-born son, Tarapipipi inherited his father's mana upon Te Waharoa's death in 1838 and soon demonstrated his talents as a peacemaker and leader (Stokes 1990: 516). In 1839 Tarapipipi was baptised by Brown at Tauranga, taking the name Wiremu Tamihana (aka William Thompson). The form of Christianity adopted by Wiremu Tamihana and other early adherents of the faith was a uniquely Māori one that incorporated the new religion into an existing framework of beliefs. In the process, Christianity was indigenised and given a distinctively Māori flavour (O'Malley 2012: 162).

Wiremu Tamihana's responsibilities as senior rangatira of Ngāti Hauā did not cease simply because of his new religion, and under his leadership the community pursued tribal success through trade and literacy rather than warfare. The new settlement at Peria that Wiremu Tamihana founded in the 1840s boasted a church, school, flour mill, post office, boarding facilities for up to 100 children, and extensive cultivations of wheat, maize, kūmara and potatoes (Firth 1890: 35-37). Wiremu Tamihana earned a reputation as one of the most progressive rangatira in the land. However, following the 
introduction of a new constitution for the colony in 1852, which effectively granted the settlers self-government while denying Māori any role, Tamihana called for Māori to be admitted on equal terms with the Europeans or alternatively for their own parallel assembly to be established (Ward 1974: 98). In the mid-1850s Tamihana travelled to Auckland to discuss these ideas with the Governor but was denied a meeting with him as he watched numerous Pākehā allowed through. He returned home after his fruitless and frustrating mission, declaring "We are treated like dogs-I shall not go again" (O'Malley 2010a: 153). It was at this point that Wiremu Tamihana threw his weight behind the fledgling Kingitanga Movement, providing crucial momentum and support. In February 1857 Wiremu Tamihana wrote to the other chiefs of Waikato, signalling Ngāti Hauā support for Pōtatau Te Wherowhero to be appointed King (Stokes 2002: 142). Pōtatau Te Wherowhero of Waikato hap $\bar{u}$ Ngāti Mahuta was widely acknowledged as one of the greatest rangatira in the land, and his whakapapa 'genealogy' was such that it connected him with many of the great founding ancestors from whom most tribes traced their descent (Jones 1968: 132).

Rewi Maniapoto of the Ngāti Maniapoto hapū Ngāti Paretekawa was also born in the early 19th century and accompanied his father, the rangatira Te Ngohi Kāwhia (also referred to as Kāwhia Te Ngohi), in battle during the inter-tribal wars of the 1830s. Like Wiremu Tamihana, he learned to read and write, gaining an early education at the Wesleyan mission station at Te Kōpua on the Waipā River (Henare 1990: 264). Rewi Maniapoto also oversaw a successful trade in agricultural produce from his settlement at Kihikihi through the two decades after 1840 . But he did not clearly identify as a Christian or eschew the need to take up arms again if required. Instead, Rewi Maniapoto was prepared to carefully guard the interests of his people by whatever means necessary; and, like Wiremu Tamihana, by 1857 he had also come to the view that these were best advanced through the Kingitanga. When a large gathering of the tribes was held at Paetai, in May 1857, to consider raising Pōtatau Te Wherowhero up as their King, Rewi Maniapoto and Wiremu Tamihana were as one in their support for this idea (O’Malley 2010a: 186).

\section{THE KĪNGITANGA}

When Pōtatau Te Wherowhero was installed as the first King in 1858, it was Rewi Maniapoto who raised the new flag at the Kingitanga headquarters at Ngāruawāhia (Henare 1990: 264). Meanwhile, it was Wiremu Tamihana who, in placing a Bible on the head of Te Wherowhero, had bestowed on him the title of Kingi 'King', for which he himself came to be referred to among many Europeans as "the kingmaker" (Jones 1960: 220-26). Although 
the Kīngitanga was seen as principally a mechanism for advancing Māori interests, many Pākehā viewed it as antagonistic to their own agenda and this way of thinking came to dominate official responses to the movement, over the voices of those who had argued in vain that it should be welcomed as a positive development (Ballara 1996: 8-9).

For opponents of the movement, the existence of supposed "moderate" and "extremist" factions within the Kīngitanga, headed by Wiremu Tamihana and Rewi Maniapoto respectively, highlighted the inherent danger of the movement, since it could be argued that, however well-meaning Wiremu Tamihana's group were, there was no guarantee that their views would triumph over those said to be agitating for direct and violent action against the settlers. This view of the King Movement as deeply factionalised and divided has long dominated the way historians have described the Kingitanga's early years, allowing the otherwise obvious point that the movement's supporters had more in common than divided them to become obscured. Moving beyond a crude binary approach that juxtaposes "good" Wiremu Tamihana against "bad" Rewi Maniapoto opens up opportunities to better understand both men on their own terms, helping to shed fresh light on what drove the Kingitanga and its leading supporters in this period.

\section{JOHN GORST AND THE ORIGINS OF THE STEREOTYPES}

Let us begin with some understanding as to the origins of the older stereotypes. It starts with the decision of various Māori from the Waikato district to intervene in the first Taranaki War in 1860, prompting the Crown to label this as a direct challenge to its own authority and setting the platform for an eventual showdown in July 1863, when a full-scale invasion of Waikato was launched. The Taranaki War had begun in March 1860, when British troops fired on local Te Ātiawa, led by Wiremu Kingi Te Rangitake, who were attempting to block the forced survey of land at Waitara that the Crown insisted it had purchased despite strong opposition from many of the customary owners (Waitangi Tribunal 1996: 77-78). By June 1860 the first reinforcements for Waitara had arrived from the Waikato, amidst talk that the King's flag was flying in Taranaki (Buddle 1860: 48)

The question of precisely which Waikato groups became involved in the Taranaki War and on what basis remains a matter of contention. The predominant viewpoint has it that Rewi Maniapoto and other "extremists", mostly belonging to Ngāti Maniapoto, ignored all injunctions to the contrary from the King and other moderates such as Wiremu Tamihana, and immersed themselves in the conflict, whether out of pure hatred of the Pākehā or in hopes of provoking an even bigger confrontation. There have been multiple variations on this argument, many of which depict Ngāti Maniapoto as almost 
fanatical in their obsession to become involved at Waitara. Perhaps the most influential commentator from this school was John Gorst, who had served as civil commissioner at Te Awamutu in the early 1860s before returning to England, where in 1864 he published his widely-cited work The Maori King; or, The Story of Our Quarrel with the Natives of New Zealand (Sorrenson 1990: 154-55). In it Gorst portrayed Ngāti Maniapoto not only as a large and powerful tribe, but also as "the most inveterate in hostility to the white race" (Gorst 1864: 24). He claimed that while many young men were animated solely by a fondness for adventure and mischief, "it was not so with Rewi Maniapoto, who having seen the war mania fairly progressing in Waikato, threw off all disguise, and went down in person to Taranaki, to pursue his design of involving the whole Maori people in a contest for supremacy with their European rivals" (Gorst 1864: 146).

In fact, Gorst went further than this, comparing and contrasting Ngāti Maniapoto and their most prominent rangatira with Ngāti Hauā and their leader. In this way, Gorst's writings provided the genesis for some enduring stereotypes and myths. He wrote in 1862 that:

... though all disaffected, two very distinct phases of disaffection are exhibited, of which the Ngatimaniapoto and Ngatihaua tribes may be looked upon as the types. Between these tribes there is a strong and bitter rivalry. One cause of this is the personal emulation of Rewi Maniapoto and William Thompson, each of whom is desirous of being the head of this King Movement, and labours to increase his own influence, and undermine that of his rival....The Ngati Maniapoto are gone mad after soldiering and warlike demonstrations. They do not care for friendship with Europeans; they do not desire law and order, and they are afraid of the introduction of English Magistrates, lest they should prove too successful in the suppression of disorder, and in the control of individual liberty. The Ngatihaua, on the other hand, are labouring to perfect their own administrations of law, and to suppress misdeeds of every kind. They gladly accept our advice, and profess a desire for our friendship. Their opposition to Sir George Grey's plans arises partly from temper, because they are mortified at having been so long overlooked, and from a distrust of the ability of English administration, and partly from losing their own independence, of which they have tasted the sweets. (Gorst 1862: 33-34)

Gorst gave as an example of this supposed division the drilled soldiers sent by the various tribes to mount guard over the Māori King at Ngāruawāhia, which had become the unofficial capital of the Kīngitanga after Pōtatau Te Wherowhero's installation as the first King in 1858. The King's guard was entirely an institution of Ngāti Maniapoto, Gorst claimed, and although Wiremu Tamihana did not oppose the idea, when the time came for Ngāti Hauā to furnish a contingent, he instead took down a group of men with 
ploughs and proceeded to plant potatoes, insisting that this was the only soldiering his tribe could do (Gorst 1862: 34). According to Gorst, a law had not long ago been passed by the Kingite tribes banning magistrates and additional schoolmasters from their lands and, although it was a practical reality in respect of Ngāti Maniapoto, Wiremu Tamihana had confessed that he only agreed to such a rule through his frequent past disappointments at being unable to secure a teacher and minister for the school he had founded within his own village. Moreover, Tamihana, according to Gorst, had urged that they should agree to proposals for Waitara to be investigated, but Wiremu Kingi, who was said to be entirely under the sway of Rewi Maniapoto, had refused to contemplate such a course (Gorst 1862: 34).

Gorst added that "strong ill-feeling is growing up between the two parties: the evidence of it consists of tones, gestures and trifling remarks, which, though sufficient to produce belief in those who witness them, cannot be so put in writing as to produce the same belief in others". He believed that both parties were making assiduous efforts to strengthen their positions, and although Rewi was in the ascendant at Ngāruawāhia, Tamihana was seeking to bolster his support at Tauranga and elsewhere in the east closer to Ngāti Hauā's own lands. Gorst added that: "In the meanwhile, the one thing which keeps the two tribes from open rupture, is their joint fear of the Government; and as long as this lasts, they will outwardly hang together. It is for this reason that any attempt on our part to promote division would probably end in postponing it, and the only plan seems to be to wait and watch" (Gorst 1862: 34).

\section{LATER HISTORIOGRAPHY}

The depiction of Ngāti Maniapoto generally and Rewi Maniapoto in particular as extremists with an almost fanatical determination to fight the British runs deep in the historiography of the New Zealand Wars, all the way from John Featon to G.W. Rusden, James Cowan to Keith Sinclair and others (McDonald 1977: 5-8). And a corollary argument is that Ngāti Maniapoto, through their actions and gestures, provoked the Crown (whether justly or unjustly) into launching an invasion of the Waikato district in July 1863, and then escaped virtually scot-free from the subsequent confiscation of lands. Even fierce critics of the Government's actions in the 1860s thus end up at least partly legitimising or justifying war and confiscation by reference to the supposed partial provocation of Ngāti Maniapoto and their leader.

Even otherwise sympathetic accounts of the Kinngitanga have sometimes followed this line. David McCan's recent history of the Waikato raupatu 'confiscation' claim, for example, declares that: 
Although it was generally [Ngāti] Maniapoto who threatened violence against Paakehaa in Taranaki, the impression was created that the three distinct entities of Raukawa, Maniapoto and Waikato were really all one people under the designation of 'Waikato tribes'. This association of Waikato with all disharmonious incidents was to be used as a justification for the invasion and confiscation of Waikato lands. (McCan 2001: 37)

Ron Crosby makes a similar comment in an even more recent work, writing of the "ultimate irony...that the lands of Ngāti Maniapoto...were left undisturbed during the confiscation process. This despite the fact that they had been the very Tainui hapū who had supported Wiremu Kingi in the fighting at Waitara, triggering the heavy-handed response of the invasion of Waikato" (Crosby 2015: 197).

On the issue of confiscation, it is entirely erroneous to claim that Ngāti Maniapoto had no lands taken from them (and equally wrong to describe them as a Tainui ' $h a p \bar{u}$ '). In fact, Rewi Maniapoto's own settlement at Kihikihi, which had been sacked and looted by Imperial troops in February 1864, was later included within the area subject to confiscation under the New Zealand Settlements Act. In all, somewhere in the vicinity of 20,000 to 50,000 acres of Ngāti Maniapoto land was confiscated. That included every last acre of Ngāti Maniapoto land that British troops and their colonial allies managed to seize. If they could have conquered more territory then they would have taken more (Belich 1986: 200). As it was, the lands confiscated were among the tribe's most valuable and productive. In the 20th century Ngāti Maniapoto filed multiple petitions and appeals concerning their confiscated lands (O'Malley 2010b: 808-20). Once again the Gorst-generated myth does not tally with the reality on the ground. They did not escape confiscation but suffered alongside other Waikato tribes (and if the argument becomes one focussed on whether the raupatu inflicted on them was proportionate, then it ultimately legitimates the whole process of invasion and land seizures by suggesting that responsibility for these things can somehow be assigned among the respective tribes).

\section{THE COUNTER-NARRATIVE}

Beyond this straightforward question of fact lurks a bigger issue as to the prevalent depiction of Ngāti Maniapoto and their leading rangatira in the historiography of the wars. Here there is a counter-narrative that deserves serious consideration. Articulated most fully amongst historians perhaps only by Ann Parsonson, James Belich and Morehu McDonald (whose thesis charts and critiques the demonisation of the Ngāti Maniapoto rangatira), this view depicts Rewi Maniapoto as a realist rather than extremist and notes substantial 
non-Maniapoto involvement in the Taranaki War. Belich, for example, states that, "The contemporary misnomers, 'moderates' and 'extremists' have stuck to the two major [Kingitanga] parties, represented by Wiremu Tamehana ('The Kingmaker') and Rewi Maniapoto respectively. But all the Kingites were united in their opposition to the sale of land" (Belich 1986: 76).

The above point would appear obvious at first. But the way in which the Kīngitanga has been depicted, emphasising tribal differences and "factions", has downplayed the extent to which it was driven by shared objectives and concerns. And as Parsonson has noted, exaggerated or alarmist accounts of divisions of opinion within the Kingitanga were used by settler governments to dismiss the movement as dangerously unstable (Parsonson 1995: 94). Talking up internal ructions made it easier to argue that the regular reassurances of the Kinngitanga's desire for peaceful co-existence with Pākehā could not be relied upon. What began as a politically-motivated justification for the invasion of Waikato has had a remarkably long appeal in the historiography of the New Zealand Wars.

A closer consideration of Rewi Maniapoto's actions in the vital period between 1860 and 1863 invites a different understanding - one not in thrall to John Gorst's alluring and enduring narrative. The depiction of Rewi as realist rather than extremist sees him as an astute reader of the contemporary political scene. As Belich (1986: 131) again put it, "At an early point in Grey's governorship, Rewi had concluded that the British intended to invade Waikato in any circumstances short of a voluntary abandonment of the King Movement. It is possible that he was quite right."

Given the public pronouncements of Governor Thomas Gore Browne (1855-61) it may not be unreasonable to conclude that Rewi had adopted this view of the Crown's intentions at an even earlier date - perhaps from the time of Browne's May 1861 statement that the Kingitanga was "inconsistent with allegiance to the Queen, and in violation of the Treaty of Waitangi" (O’Malley 2010a: 370).

If Rewi is reimagined as realist rather than extremist, then perhaps Wiremu Tamihana might also need to be rethought as idealist rather than moderate, his belief that the Kingitanga might be allowed to co-exist with the Crown being based more on a principled worldview than anything more concrete. Not that his view was entirely unrealistic. Some Europeans shared Tamihana's conviction that some form of co-existence was possible, and their assessments found some sympathy within the Colonial Office, which was open to the possibility of declaring Waikato a self-governing "native district" under Section 71 of the New Zealand Constitution Act of 1852. But the problem was that both Governor Browne and his successor George Grey (with the support of colonial ministers), proved more interested in demanding submission to the Crown than in reaching out for some kind of reconciliation (Ward 2008: 95). 
Wiremu Tamihana's outlook was shaped in part by his Christian beliefs (hence the frequent biblical references in support of his actions). Importantly, he also operated on the basis of an apparent assumption that the Pākehā governors, officials and politicians he dealt with-nearly all of whom similarly professed to be Christians - shared those same ideals. As such, resolving contentious issues was simply a matter of appealing to common Christian convictions. That the Europeans he dealt with might not act in accordance with the Christian precepts they professed to share seems to have been beyond his comprehension. It was this that made Wiremu Tamihana an idealist. It also brought a great deal of anguish - in the wake of the Waikato War Tamihana described in a series of petitions the hurt, pain and confusion he had felt at being branded a warmonger by Pākehā when so much of his life had been devoted to the cause of peace (Stokes 2002: 455-91). "Am I a man of murder", he asked in one, observing "I only fought for my body and my land; I had not any wish to fight" (Tamihana 1865: 3).

Yet Wiremu Tamihana was no fool, and his actions and beliefs were also governed by his standing as a senior rangatira. For great chiefs, maintenance of their own mana was dependent at least in part on acting honourably and with integrity. In return, they expected those they dealt with to behave likewise, and Tamihana's dealings with senior Crown figures (the Pākehā equivalent of rangatira) can be seen as reflecting this way of thinking. A great chief's word was their bond and Tamihana had every reason to believe the Pākehā politicians he dealt with when considered within this framework. His behaviour was consistent with the mark of a true rangatira, while also being in line with his long-established role as a peacemaker dating back to the 1830s. In speaking truth to power, Wiremu Tamihana was acting precisely as a great chief ought to have done.

Rewi Maniapoto's actions were also consistent with those of a rangatira seeking to protect his people. He was also a man of principles, guided by his understanding of appropriate chiefly behaviour, and in this sense these ideals shaped the nature of his interactions with others. But his outlook was different and so was his focus. Although he had long interacted with Anglican, Wesleyan and Catholic missionaries in the upper Waikato, Rewi adopted a more sceptical and less trusting worldview, one that equipped him to understand the realpolitik of Māori and settler relations in the mid-19th century far better than Wiremu Tamihana. As Morehu McDonald has argued:

Rewi was a political realist. He understood better than most of his contemporaries the uncompromising power and ambitions of European colonialism. Certainly the Maori King Movement had been inaugurated in 1858 as a defensive innovation to halt the advancing tide of European settlement, and was a focus for Maori nationalism and distrust of European 
Government. However, its moderate and somewhat idealistic leaders preferred to adopt the traditional 'taihoa' (wait-and-see) policy which left them basically unprepared, politically, psychologically and militarily for the turn of events which led to the invasion of the Waikato in July 1863. What Rewi attempted to confer on Maori political leaders in this period was the realistic course of facing European aggression and preparing for the inevitability of war in defence of their homelands. (McDonald 1977: 10-11)

McDonald argues that Rewi Maniapoto's skills as a military leader have if anything been overrated by most historians, who have conversely ignored or underplayed his political foresight and ability (McDonald 1977: 11). The rangatira's political strategy, he argues, was a relatively straightforward one:

... preserve both Waikato and Ngati Maniapoto tribal lands from European encroachment by giving support, politically and militarily to the King Movement; and military assistance to their Taranaki allies. If Taranaki and Waikato survived European pressure, Ngati Maniapoto lands would also be secure. If, however, these two tribal 'buffer zones' were successfully invaded and occupied by Europeans, Ngati Maniapoto would find itself fighting on two fronts - a grave strategical error - without support from the defeated Waikato and Taranaki tribes. Survival of these two tribal territories meant survival for Ngati Maniapoto, while on the other hand, the defeat of the Waikato and Taranaki 'buffer zones' would also mean the ultimate defeat, politically and militarily, of Ngati Maniapoto. (McDonald 1977: 11-12)

Once he had become resigned to the inevitability of a showdown, McDonald adds, Rewi Maniapoto sought to unite all Māori in defence of a common homeland where they might all continue to live under their own laws and leaders. But old fears, rivalries and factionalism undermined the success of such an approach, and some older chiefs suspected Rewi was simply looking to boost his own mana or standing (McDonald 1977: 12).

Ngāti Maniapoto were "the colonists' favourite bogeymen", but even the Crown's own contemporary records make it abundantly clear that they were far from the only Waikato tribe to become involved in the Taranaki War (Belich 1986: 145). ${ }^{1}$ Besides Ngāti Maniapoto, Ngāti Hauā, Ngāti Raukawa, Ngāti Mahuta and other groups were liberally represented among the defenders of Waitara after June 1860. Indeed, Ngāti Hauā took a prominent role in the Mahoetahi battle fought on 6 November 1860, suffering very heavy losses in the engagement, including one of their most prominent rangatira, Te Wetini Taiporutu (Prickett 2005: 97-103). It was said that the Waitara dispute was given over to Wiremu Tamihana to settle in the wake of this battle in consideration of those of his tribe who had been killed (although it might also have reflected his acknowledged skills and experience as a peacemaker). In 
fact, on the eve of the invasion of Waikato in 1863, one correspondent for the Daily Southern Cross newspaper attributed the Waikato tribes' ardent desire for peace to what had occurred at Taranaki some three years earlier. It was said that:

The disinclination to go to war with the troops which now exists throughout Waikato, is greatly owing to the losses the tribes of that district sustained during the Taranaki war three years ago. The Ngatihaua lost the greatest number, and are now the most peaceably inclined. One can scarcely find a village in the Waikato without a cripple in it; one has got his lower jaw shot away, and has since subsisted on spoon diet; a second is lame, and great numbers are disfigured more or less. Another reason of the aforesaid disinclination is that the Maoris consider that they have no quarrel with the Government, and they do not intend to make one; therefore Auckland people need have no fear whatever of attack by the Waikato Maoris, as these are all well employed cultivating their soil, the Ngatimaniapoto being the only disaffected tribe, and they being well convinced that they have no chance of success in an attack upon either the troops or the European villages near Auckland. In fact the Waikatos are more afraid of the Governor than Europeans are of the Maoris. ... Auckland was never more safe than it is at present from an attack by the Waikato Maoris. ${ }^{2}$

But if Rewi was preparing to defend his territory from attack, he was also willing to explore opportunities to peacefully resolve matters. Late in 1862, for example, Rewi personally invited Governor Grey to Waikato. Grey's subsequent dramatic and unscheduled visit on New Year's Day in 1863 might have finally convinced Rewi that the Kingitanga would not be permitted to survive. It was during the course of this hui 'meeting or assembly' that Grey had declared that he would dig around the King until he fell of his own accord (Gorst 1864: 324). Rewi subsequently cited this statement in defence of his decision to expel Gorst from Te Awamutu in April. ${ }^{3}$

\section{THE WAIKATO WAR}

Later, in the run up to the invasion of Waikato in July 1863, Rewi Maniapoto stood accused not just of ordering the attack on British troops at Ōakura on 4 May that re-ignited the Taranaki War for the first time since the truce brokered by Wiremu Tamihana early in 1861, but also of plotting an imminent assault on Auckland. This alleged plan was said to have compelled the Crown to take preemptive action by moving troops into Waikato. There was just one problem with this scenario: Rewi Maniapoto was actually returning from a tangi or 'mourning ceremony' in Taupō when he received news from a messenger that British troops had crossed the Mangatāwhiri River, widely understood and acknowledged as the boundary between Kinngitanga and Crown-controlled 
territories (O'Malley 2013: 46). If, as his accusers alleged, he was on the verge of laying waste to Auckland at this very time, then his preparations were baffling indeed. But in reality Rewi had no such intention. Believing that war was inevitable, and wishing to strike first before the British troops had completed their own preparations, Rewi had argued in favour of a preemptive strike against the British position at Te Ia, in the Waikato. But Wiremu Tamihana's argument that if a war must be fought then it should be a just and righteous one, and that this would be forfeited if the Kingitanga struck first, carried the day. Following this hui, held at Ngāruawāhia probably in May or early June, Rewi had abided by the wishes of the majority and travelled south to Taupo, abandoning plans to attack the British troops who were beginning to assemble in ever greater numbers along the Waikato frontier. As Renata Kawepo and other Hawke's Bay chiefs who inquired into the causes of the Waikato War later told Isaac Featherston, "Rewi proposed then to fight, but it was disapproved by Matutaera, by Tamehana, by Te Paea, and the Chiefs of Waikato. In consequence of their strong opposition, Rewi desisted, and he came to Taupo to the tangi for (the death of) Te Heuheu". ${ }^{4}$ Rewi was himself said to be planning to visit Hawke's Bay in the near future-hardly ideal preparation for an attack on Auckland.

Rewi Maniapoto would become the fall guy for a deliberate Crown war of conquest. It was much harder to tar Wiremu Tamihana with the same brush, though that did not stop some people from trying. A friendly warning to Tauranga missionary Alfred Brown to be on his guard was for these purposes twisted into a sinister statement of intent (Sewell 1864: 34). That was made even more challenging by the fact the letter was drafted two weeks after the war had already commenced and by Brown's forceful defence of Tamihana.

When the British troops found themselves short of provisions in the early stages of the war due to successful Māori assaults on their supply lines, Wiremu Tamihana sent their commander, Lieutenant-General Duncan Cameron, via the loyalist chief Wiremu Te Wheoro, goats, turkeys and other provisions, accompanied by a letter citing the old scriptural injunction that "when thine enemy hunger feed him, when he thirst give him drink" (Anon. 1863). Although perhaps intended as an act of Christian charity, Tamihana's gesture was also consistent with how a rangatira of great mana and standing might behave - that is, in an honourable and generous manner. In Wiremu Tamihana we see both the chiefly and Christian imperatives intertwined, making it difficult at times to disentangle these (even were that considered necessary or desirable).

As for Rewi Maniapoto, his actions during the Waikato War belied the image of a war-crazed "savage" previously advanced. Not only did he insist on fighting fairly and honourably throughout the war, but on multiple occasions 
he also urged caution. When his own settlement of Kihikihi was torched and destroyed by British troops on 23 February 1864, Rewi and his followers watched the sad spectacle unfold from a hill across the river, resisting the temptation to try and prevent the sacking and deliberate destruction of their village. Meanwhile, during the course of the Ōrākau siege just over a month later, some of the Urewera chiefs, perhaps remembering the British actions at Rangiriri in November 1863 (when the $p \bar{a}$ had controversially been seized under a white flag), advocated hoisting a white flag of their own and firing on the troops as they advanced towards the $p \bar{a}$. This suggestion was overruled by others (probably including Rewi Maniapoto) who declared that they "would not agree to such treachery, because this was not after the manner of chiefs" (Te Paerata 1888: 5).

Rewi Maniapoto had previously intervened to prevent one of his men from cutting out the heart of a dead young soldier who had fallen just outside the $p \bar{a}$ 's defences in the early attempts to storm it, even though it was customary to make a sacrificial offering of the first fallen in this way, reportedly insisting that "we are fighting under the religion of Christ" (Cowan 1983 [I]: 381). For all of the attempts on the part of the British to portray Rewi as a man of violent and savage temperament, he appears to have been more of a stickler for appropriate military etiquette than were some of the British commanders (whose actions in attacking Rangiaowhia in February 1864, even though the village was considered a place of sanctuary for women, children and the elderly, was denounced by the Kingitanga as contrary to the accepted norms of warfare). As for the supposed divisions between the two chiefs, it bears remembering that Rewi Maniapoto was on his way to consult Wiremu Tamihana about the future conduct of the war when he was stopped by a Tūhoe party en route and persuaded, against his better judgement, to take a stand at Ōrākau (Cowan 1983 [I]: 367).

\section{CONCLUSION}

The perception that a hardcore element existed within the King Movement that posed a serious threat to the Crown and settlers was promoted to justify a deliberate war of conquest in 1863, and endures to some extent today. Observers then and since have identified this "extremist" faction as being headed by Rewi Maniapoto and backed by the solid support of many other Ngāti Maniapoto tribal members. The implication advanced by a number of contemporary observers and later historians has often been that it was through the actions of Ngāti Maniapoto and their leader that Waikato was invaded by British troops in 1863 and the district confiscated. That argument comes dangerously close to legitimising the Crown's actions at Waikato as having been at least in part provoked by Ngāti Maniapoto. But it is also a viewpoint 
that fails to stack up on closer scrutiny. For one thing, the depiction of the Kingitanga as a deeply divided movement loses sight of the fact that figures such as Rewi Maniapoto and Wiremu Tamihana had more in common than divided them. Moreover, at various times Rewi Maniapoto demonstrated a genuine interest in negotiating mutually agreeable terms with the Crown, even while making it clear that he was prepared to fight in defence of the Kingitanga should this prove necessary. Ultimately, Wiremu Tamihana was also willing to take up arms in defence of the King Movement. For Wiremu Tamihana the war was both shocking (in its origins and conduct, such as the attack on Rangiaowhia), as well as being deeply depressing. For Rewi Maniapoto the conflict was at least not surprising, since he had long held that such an outcome would be inevitable so long as Waikato Māori refused to voluntarily disband the Kinngitanga. That was a realistic perspective. Rewi Maniapoto did not start the Waikato War. But (unlike Wiremu Tamihana), he did anticipate it.

Contrasting "moderate" Wiremu Tamihana with "extremist" Rewi Maniapoto creates a false binary. Both rangatira were staunch defenders of the Kingitanga they helped create. Both were deeply principled men in their own way and both acted precisely as befitted their statuses as great chiefs. That John Gorst's alternative view, juxtaposing "good" Wiremu Tamihana against "bad" Rewi Maniapoto, has been allowed to stand for so long flies in the face of this evidence. We should remember these two great rangatira on their own terms and in their own way.

\section{ACKNOWLEDGEMENTS}

I am grateful to the two anonymous reviewers of the manuscript for their thoughtful and constructive suggestions and recommendations.

\section{NOTES}

1. See, for example, the various reports of "rebel" Māori killed or wounded and their tribal affiliations: New Zealand Gazette, 7 November 1860, No. 33, p. 190; New Zealand Gazette, 28 January 1861, No. 5, p. 23.

2. Daily Southern Cross, 6 July 1863.

3. Gorst to Bell, 1 April 1863. Appendix to the Journals of the House of Representatives, 1863, E-1, pp. 13-14.

4. Renata Tamakihikurangi and others to Featherston, 19 October 1863. AJHR, 1863, E-11, p. 4.

\section{REFERENCES}

Anon. [1863]. Diary of a British Solder, Queen's Redoubt, 25 August 1863. Micro0445. Alexander Turnbull Library (ATL), Wellington.

Appendices to the Journals of the House of Representatives (AJHR). 
Ballara, Angela, 1991. The Origins of Ngāti Kahungunu. Unpublished PhD thesis, Victoria University of Wellington.

1996. Introduction. In Te Kingitanga: The People of the Māori King Movement: Essays from the Dictionary of New Zealand Biography. Auckland and Wellington: Auckland University Press with Bridget Williams Books and Department of Internal Affairs, pp. 1-32.

1998. Iwi: The Dynamics of Māori Tribal Organisation from c. 1769 to c.1945. Wellington: Victoria University Press.

2003. Taua: 'Musket Wars', 'Land Wars'or Tikanga? Warfare in Māori Society in the Early Nineteenth Century. Auckland: Penguin Books.

Belich, James, 1986. The New Zealand Wars and the Victorian Interpretation of Racial Conflict. Auckland: Auckland University Press.

Buddle, Thomas, 1860. The Maori King Movement in New Zealand, with a Full Report of the Native Meetings Held at Waikato, April and May, 1860. Auckland: Office of the New Zealander.

Cowan, James, 1983. The New Zealand Wars: A History of the Maori Campaigns and the Pioneering Period. 2 vols. Wellington: Government Printer.

Crosby, Ron, 2015. Küpapa: The Bitter Legacy of Māori Alliances with the Crown. Auckland: Penguin.

Daily Southern Cross, 6 July 1863.

Durie, E.T, 1994. Custom Law. Unpublished research paper, Wellington.

Firth, J.C., 1890. Nation Making: A Story of New Zealand: Savagism v. Civilization, London: Longmans, Green and Co.

Gorst, J.E., 1864. The Maori King; or, The Story of Our Quarrel with the Natives of New Zealand. London: Macmillan \& Co.

1862. Report on the State of the Upper Waikato District, March 1862. Appendices to the Journals of the House of Representatives (AJHR) 1863, E-4, pp. 33-34.

Henare, Manuka, 1990. Rewi Manga Maniapoto. In W.H. Oliver (ed.), The Dictionary of New Zealand Biography, Volume One, 1769-1869. Wellington: Allen \& Unwin and Department of Internal Affairs, pp. 263-65.

Jones, Pei Te Hurinui, 1960. King Potatau: An Account of the Life of Potatau Te Wherowhero, the First Maori King. Wellington: The Polynesian Society. 1968. Maori kings. In Erik Schwimmer (ed.), The Maori People in the NineteenSixties. Auckland: Blackwood and Janet Paul, pp. 132-73.

McCan, David, 2001. Whatiwhatihoe: The Waikato Raupatu Claim. Wellington: Huia Publishers.

McDonald, Brian Morehu, 1977. Rewi Manga Maniapoto: A Study in the Changing Strategies of Nineteenth Century Maori Political Leadership. Unpublished PhD thesis, University of Auckland.

New Zealand Gazette, 7 November 1860, No. 33, p. 190; 28 January 1861, No. 5, p. 23.

O'Malley, Vincent, 2010a. Te Rohe Potae Political Engagement, 1840-1863. Unpublished research report, Waitangi Tribunal, Wellington.

2010b. Te Rohe Potae War and Raupatu. Unpublished research report, Waitangi Tribunal, Wellington. 2012. The Meeting Place: Māori and Pākehā Encounters, 1642-1840. Auckland: Auckland University Press. 
2013. Choosing peace or war: The 1863 invasion of Waikato. New Zealand Journal of History 47 (1): 39-58.

Parsonson, Ann, 1981. The pursuit of mana. In W.H. Oliver with B.R. Williams (eds), The Oxford History of New Zealand. Wellington: Oxford University Press, pp. 140-67.

_ 1995. Tainui Claims to Onewhero and Maramarua Forests: Historical Overview-A Report for Tainui. Unpublished research report, Tainui Maori Trust Board, Hamilton.

Prickett, Nigel, 2005. Maori Casualties of the First Taranaki War, 1860-61. Auckland: Auckland War Memorial Museum.

Sewell, Henry, 1864. The New Zealand Native Rebellion: Letter to Lord Lyttleton. Auckland: Printed for the Author.

Sorrenson, M.P.K., 1990. John Eldon Gorst. In W.H. Oliver (ed.), The Dictionary of New Zealand Biography, Volume One, 1769-1869. Wellington: Allen \& Unwin and Department of Internal Affairs, pp. 154-55.

Stokes, Evelyn, 1990. Wiremu Tamihana Tarapipipi Te Waharoa. In W.H. Oliver (ed.), The Dictionary of New Zealand Biography, Volume One, 1769-1869. Wellington: Allen and Unwin and Department of Internal Affairs.

2002. Wiremu Tamihana: Rangatira. Wellington: Huia Publishers.

Tamihana, Wiremu, 1865. Petition of William Thompson, Te Waharoa. AJHR, 1865, G-6.

Te Paerata, Hitiri, 1888. Description of the Battle of Orakau, As Given by the Native Chief Hitiri Te Paerata of the Ngatiraukawa Tribe, At the Parliament Buildings, 4th August 1888. Wellington: Government Printer.

Waitangi Tribunal, 1996. The Taranaki Report: Kaupapa Tuatahi, Wellington: GP Publications.

Ward, Alan, 1974. A Show of Justice: Racial 'Amalgamation' in Nineteenth Century New Zealand. Auckland: Auckland University Press and Oxford University Press. -1997. National Overview (Waitangi Tribunal Rangahaua Whanui Series). 3 vols. Wellington: Legislation Direct.

2008. A "savage war of peace"? Motives for government policies towards the Kingitanga, 1857-1863. In Richard Boast and Richard S. Hill (eds), Raupatu: The Confiscation of Maori Land. Wellington: Victoria University Press, pp. 67-109. Winiata, Maharaia, 1967. The Changing Role of the Leader in Maori Society: A Study in Social Change and Race Relations. Auckland: Blackwood and Janet Paul.

\begin{abstract}
The depiction of Ngāti Maniapoto generally and Rewi Maniapoto in particular as extremists with an almost fanatical determination to fight the British runs deep in the historiography of the New Zealand Wars, all the way from John Featon to G. W. Rusden, James Cowan to Keith Sinclair and others. And a corollary argument is that Ngāti Maniapoto, through their actions and gestures, provoked the Crown (whether justly or unjustly) into launching an invasion of the Waikato district in July 1863, and
\end{abstract}


then escaped virtually scot-free from the subsequent confiscation of lands. Even fierce critics of the government's actions in the 1860s thus end up at least partly legitimising or justifying war and confiscation by reference to the supposed partial provocation of Ngāti Maniapoto and their leader. Their stance is often contrasted with that of Wiremu Tamihana, who is said to have been leader of the "moderate" Kinngitanga faction. This article argues that the differences between the two rangatira have been overstated. Wiremu Tamihana and Rewi Maniapoto had more in common than divided them. Furthermore, rather than conceptualising this in terms of "moderate" versus "extremist", the difference between the two rangatira might be better conceptualised as idealist versus realist. Considered within the context of Māori custom, moreover, both men operated within the accepted limits of chiefly behaviour, which was concerned above all with questions of mana.

Keywords: Rewi Maniapoto, Wiremu Tamihana, rangatira, Māori, Waikato War, chiefly behaviour

\section{CITATION AND AUTHOR CONTACT DETAILS}

O’Malley, ${ }^{1}$ Vincent, 2016. A Tale of Two Rangatira: Rewi Maniapoto, Wiremu Tamihana and the Waikato War. Journal of the Polynesian Society 125(4): 341-357. DOI: http://dx.doi.org/10.15286/jps.125.4.341-357

${ }^{1}$ Correspondence: HistoryWorks, P.O. Box 27-043, Wellington, New Zealand. Email: vincent.omalley@historyworks.co.nz 
